\title{
Expression of circadian clock gene human Period2 (hPer2) in human colorectal carcinoma
}

Yaping Wang ${ }^{1}$, Luchun Hua ${ }^{*}$, Chao Lu ${ }^{2}$ and Zongyou Chen ${ }^{1}$

\begin{abstract}
Background: Recent studies have shown that disruption of circadian rhythms is one of the tumor promoting factors which contribute to mammalian cancer development and progression, but very little is known about the molecular changes of circadian genes in colorectal carcinoma (CRC). Thus, in this study, changes in the expression of human Period2 (hPer2), one of the key circadian clock regulators, in CRC and its correlation with prognosis were investigated.

Methods: Immunohistochemical (IHC) staining and real-time PCR for hPer2 were performed for 38 CRC cases.

Results: $I H C$ analysis detected positive staining for hPer2 in $81.6 \%$ (31/38) of CRC tissues and $97.4 \%$ (37/38) of surrounding non-cancerous tissues $(P<0.05)$. Most colorectal cells in non-cancerous tissues were homogeneously stained. In contrast, in the paired cancerous tissues, a heterogeneous pattern was found with a significant portion of cancer cells displaying negative or weak hPer2 staining. In over $60 \%$ cases (24/38), the staining for hPer2 was much stronger in non-cancerous cells than in the paired cancerous cells. Well-differentiated cancer cells are more likely to maintain hPer2 expression than poorly-differentiated ones. Furthermore, associations of decreased hPer2 levels with patients' age, histological grade, TNM stage and expression of nucleus proliferation related antigen: Ki67 were also detected $(P<0.05)$. Expression of hPer2 did not correlate with that of either p53 or $\mathrm{C}$-erB-2. Similar to hPer2 protein expression, quantitative RT-PCR for hPer2 also showed decreased mRNA expression in CRC.

Conclusion: These results suggest a role for hPer2 in normal colorectal cell function and the potential deregulation of hPer2 expression in the development, invasion, and metastasis of CRC.

Keywords: circadian, clock gene, human Period2 (hPer2), colorectal carcinoma, expression
\end{abstract}

\section{Background}

Various kinds of living organisms exhibit behavioral and physiological circadian rhythms, allowing them to adapt to the daily cycle of light and dark [1]. At the molecular level, the rhythms of the circadian clock are controlled by the interaction between positive and negative feedback loops consisting of several key clock regulators $[2,3]$. A model encompassing a feedback system involving heterodimer transcriptional factors (Clock and Bmal1), two cryptochromes (Cry1 and Cry2), and three Period (Per1, Per2, and Per3) regulators has been widely described.

\footnotetext{
* Correspondence: drhua@126.com

'Department of Surgery, Huashan Hospital, Fudan University, Shanghai, China

Full list of author information is available at the end of the article
}

Among all the known clock genes, Per2 has been shown to play an important role in tumor progression $[4,5]$. Dysregulation of hPer2 gene has been found in many types of human cancers [6,7]. Genetic studies also showed that mice with dysfunctional circadian rhythms are prone to many kinds of cancer developing $[8,9]$. Mice deficient in mPer2 showed significant higher tumor incidence [10]. Moreover, functional studies found that overexpression of Per2 inhibited cancer cell growth in both culture system and xenograft mouse model [11-13]. In terms of the mechanisms, C-erB-2 and p53 were suggested to act as the downstream players for hPer2 in the course of tumor progression $[7,10,14]$. Both the C-erbB-2 oncogene and the p53 tumor-suppressor gene integrate numerous signals that control cell proliferation and survival. As when a highly connected node in the internet breaks down, the
Ciomed Central

() 2011 Wang et al; licensee BioMed Central Ltd. This is an Open Access article distributed under the terms of the Creative Commons Attribution License (http://creativecommons.org/licenses/by/2.0), which permits unrestricted use, distribution, and reproduction in any medium, provided the original work is properly cited. 
activation of C-erbB-2 or disruption of p53 leads to severe consequence of tumorigenesis [15-17]. Although hPer2 is implicated as a tumor suppressor, the expression pattern of hPer2 in cancer is not quite clear. Whether hPer2 expression is associated with other tumor-associate proteins such as C-erB-2 and p53 in human CRC remains uncertain.

Colorectal cancer is one of the most commonly seen malignancies and the leading cause of cancer related death worldwide. About 141,210 new cases and 49,380 deaths were expected for 2011 in the United States [18]. In China, CRC is the fourth leading cause of cancer mortality in big cities and the fifth in countryside. However, in Shanghai, CRC incidence and mortality rates ranked the second and third respectively for female [19]. Since surgical approaches and conventional therapeutic have not been able to fully control the outcomes of $\mathrm{CRC}$, there is an urgent need to develop more effective treatments.

The circadian rhythm is interconnected with many aspects of cellular functions such as cell proliferation, migration and differentiation, thus, it plays a major role in regulating the digestive system [20,21]. Many laboratories have reported strong evidence about the beneficial effects of chronotherapy, which refer to chemotherapy delivery according to the circadian rhythm [22,23]. Phase I-III clinical trials have shown that chronotherapy significantly increased tolerance to high doses of chemotherapy drugs and improved clinical response in patients with metastatic colorectal cancer $[24,25]$. These findings further interest us to explore the relationship between circadian rhythms and CRC at molecular level. In the present study, we used immunohistochemical staining and real-time PCR to characterize the role of hPer2 in the development of human CRC.

\section{Methods}

\section{Tissue samples}

38 resected CRC samples and paired non-cancerous tissues were obtained from the patients of Huashan hospital, Shanghai, China, undergone radical surgery for colorectal cancer (20 males and 18 females). All patients had a definitive pathological diagnosis and accepted neither chemotherapy nor radiotherapy before operation. The samples were surgically obtained at the following points: 23 cases between 10:00 and 12:00, 8 cases between 12:00 and 14:00, 3 cases between 14:00 and 16:00, 3 cases between 16:00 and 18:00, and 1 case at 22:00. After surgical removal, the samples were preserved in liquid nitrogen immediately and then moved to the $-80^{\circ} \mathrm{C}$ freezer for long term storage. The age of the patients, tumor site, tumor type, histological grade and TNM stage according to AJCC classification were recorded.

\section{Immunohistochemistry}

Frozen tissues were cut into $4 \mu \mathrm{m}$ - thick sections and adhered to slides at $-20^{\circ} \mathrm{C}$, fixed by acetone and stored in the $-20^{\circ} \mathrm{C}$ refrigerator. Endogenous peroxidase activity was blocked by incubation of sections in $3 \% \mathrm{H}_{2} \mathrm{O}_{2} /$ methanol. Sections were covered with pre-block solution at $37^{\circ} \mathrm{C}$ for 30 minutes, followed by Per2 antibody (1:50, Santa Cruz biotechnology) incubation for 60 minutes at $37^{\circ} \mathrm{C}$. After a brief wash with PBS, biotinylated secondary antibody was added with 60 minutes at $37^{\circ} \mathrm{C}$. After several washes with PBS, staining was achieved using 3 , 3'-diaminobenzidine for about 5 10 minutes. Finally, slides were counterstained with Mayer's hemalum and mounted. Appropriate positive and negative controls were also included. The frozen sections were also stained with C-erB-2(sp3, dako), p53 (DO-7, dako) and Ki67 (Ki-S5, dako) by the same method.

\section{Grading of immunohistochemical findings}

Immunohistochemical findings were scored depending on the extent and intensity of staining. All sections were graded by two independent investigators without knowing the patient's outcome. At least 10 randomly selected high - power fields were scored, and the average score was recorded.

\section{RNA extraction and first-strand CDNA synthesis}

Preparation of total RNA from tissue samples was done using the Trizol reagent (Invitrogen Co.). The amount of total RNA was determined by UV spectrophotometry, and RNA integrity was assessed by agarose gel electrophoresis. First-strand cDNA was prepared with oligo-dT primers using a commercial cDNA synthesis kit (Fermentas RevertAId ${ }^{\mathrm{TM}}$ ). The cDNA was then amplified for 33 cycles with specific primers for Per2 and GAPDH which was utilized as an internal reference (table 1). Sequence data were analyzed using the Basic Local Alignment Search Tool (BLAST) software located at the National Centre for Biotechnology Information (NCBI) web site: http://www.ncbi.nlm.nih.gov web site.

The PCR reactions containing SYBR-green were amplified on a Corbett Real Time PCR machine (BioRad, USA). After reverse transcription, the cDNA was diluted with sterile deionized water to 10 -fold. The reaction mixtures for PCR contained $5 \mathrm{~mL}$ of diluted cDNA, $1 \mathrm{~mL}$ of $10 \mathrm{mmol} / \mathrm{L}$ primers $(0.5 \mathrm{~mL}$ of forward primers,

Table 1 Primer pairs used for real-time PCR

\begin{tabular}{lll}
\hline & primer $\left(\mathbf{5}^{\prime}\right.$-' $\left.\mathbf{3}^{\prime}\right)$ & Product length \\
\hline hPer2 & Forward:TCCAGTGGACATGAGACCAA & $186 \mathrm{bp}$ \\
& Reverse:CGCTACTGCAGCCACTTGTA & \\
GAPDH & Forward:AACCTGCCAAATATGATGAC & $191 \mathrm{bp}$ \\
& Reverse:ATACCAGGAAATGAGCTTGA & \\
\hline
\end{tabular}


$0.5 \mathrm{~mL}$ of reverse primers), $12.5 \mathrm{~mL}$ of real-time PCR Master Mix (TOYOBO Co.), and $6.5 \mathrm{~mL}$ of $\mathrm{H}_{2} \mathrm{O}$, into a final volume of $25 \mathrm{~mL}$. After an initial incubation for 5 min at $94^{\circ} \mathrm{C}$, the samples were subjected to 33 cycles of amplification (denaturation at $94^{\circ} \mathrm{C}$ for $30 \mathrm{sec}$, primer annealing at $52^{\circ} \mathrm{C}$ for $45 \mathrm{sec}$, extension at $72^{\circ} \mathrm{C}$ for 45 sec) with the final incubation for $15 \mathrm{~min}$ at $72^{\circ} \mathrm{C}$.

After each real-time PCR, melting profiles as well as agarose gel electrophoresis of each sample were done to rule out the possibilities of nonspecific PCR products and primer dimers. Each $4 \mu \mathrm{L}$ of PCR product was electrophoresed on $2 \%$ agarose gel and visualized with UV transilluminator. Data was acquired as threshold cycle $(\Delta \mathrm{Ct})$ value. As internal standard to normalize mRNA levels for differences in sample concentration and loading, amplification of GAPDH was used. Standard curves were constructed for each target gene and internal control by plotting $\Delta \mathrm{Ct}$ values versus $\log \mathrm{cDNA}$ dilution. Because the amplification efficiencies of target genes and internal control were equal, the relative changes of target gene expression in tumor cells compared with normal colorectal mucosa ( $\Delta \mathrm{Ct}$ calibrator value) were calculated using the equation $2^{-\Delta \Delta \mathrm{Ct}}$, where $\Delta \Delta \mathrm{Ct}=\Delta \mathrm{Ct}$ (cancer)- $\Delta$ (non-cancer). The $\Delta \mathrm{Ct}$ values were determined by subtracting the average GAPDH Ct value from the average target gene $\mathrm{Ct}$ value.

\section{Statistical analysis}

Comparison between the expression of hPer2 mRNA levels in normal colorectal mucosa and tumor tissue of patients was done by paired t-test, Ki67 level with hPer2 protein expression was done by $\mathrm{t}$-test, and $\chi^{2}$-test or Fisher exact test was performed to analyze the correlations of hPer2 protein levels with clinical and pathologic parameters. SPSS, 16.0 was used in the above data analysis. P-values of less than 0.05 were considered to be statistically significant.

\section{Results}

\section{Immunohistochemical analyses of hPer2 protein expression}

To investigate whether hPer2 gene was deregulated in colorectal cancer, we first examined hPer2 protein expression in 38 paired colorectal cancerous and noncancerous tissues by IHC staining. hPer2 expression was found in both cytoplasm, and nucleus. The results revealed that positively stained cells can be found in 81.6\% (31/38) of colorectal carcinoma tissues (Figure $1 \mathrm{~A})$ and $97.4 \%(37 / 38)$ of surrounding non-cancerous tissues (Figure 1B) $(\mathrm{P}<0.05)$. Most colorectal cells in non-cancerous tissues were homogeneously stained. In contrast, in the paired cancerous tissues, there was a significant portion of cancer cells displaying negative or weak staining. This heterogeneous staining phenomenon was frequently observed in our study. Moreover, welldifferentiated cancer cells tend to have comparable hPer2 level with that in non-cancerous cells (Figure 2), suggesting that loss of hPer2 expression may associate with increased aggressiveness. For these 38 cases, the hPer2 protein expression in colorectal tissues exhibited three different patterns: typeI (24 cases): the staining for hPer2 was much stronger in non-cancerous cells than in the paired cancerous cells; type II (12 cases): there were no significant differences between the staining of cancerous and non-cancerous cells; type III ( 2 cases): the staining for hPer2 was stronger in cancerous cells than in the paired non-cancerous cells.

\section{Correlation between hPer2 protein expression and} clinical-pathological features in colorectal cancer patients In order to establish the clinical and pathological relevance of low expression of hPer2 protein in human colorectal cancer, we assessed the relationship between hPer2 expression and clinical-pathological parameters. The results are shown in table 2 table 3 and table 4 . Decreased hPer2 expression were found in all the younger patients with age no more than 50 while only $53 \%$ patients in the older group had low hPer2 expression. However, no correlations were found between low hPer2 expression and sex or tumor site.

Low hPer2 expression is also found to be correlated with higher histological grade $(\mathrm{p}<0.017)$, deeper tumor invasion $(\mathrm{P}<0.044)$, positive lymph nodes metastasis $(\mathrm{P}$ $<0.043)$ as well as more advanced TNM stage ( $\mathrm{P}<$ $0.021)$. In order to further understand the potential role of hPer2 at molecular level, Ki67, a proliferation marker, was also evaluated. And we found that tumors with low hPer2 expression displayed higher Ki67 score than that without, consistent with the notion that losing hPer2 expression may promote cancer cell growth. However, there were no statistical differences between hPer2 expressions with expressions of $\mathrm{p} 53$ or C-erB-2.

\section{Determination of hPer2 mRNA level by real-time PCR}

We further analyzed hPer2 mRNA levels in these 38 paired cancerous and non-cancerous tissues by real-time PCR. The amount of hPer2 mRNA was normalized using the endogenous reference GAPDH. The normalized hPer2 mRNA expression $(\Delta \mathrm{Ct})$ of tumor tissue was then compared with the $\Delta \mathrm{Ct}$ of the paired non-tumor tissues from the same colorectal cancer patient to determine their relative expression levels $(\Delta \Delta \mathrm{Ct})$ (Figure 3). Then we analyzed hPer2 mRNA expressions in these 24 paired tissues which showed low expression of hPer2 protein in tumor. Our results showed that the mRNA levels of hPer2 in colorectal cancer were decreased compared with those in paired non-tumor tissues $(\mathrm{P}<0.05)$. The relative expression levels $\left(2^{-\Delta \Delta \mathrm{Ct}}\right)$ of hPer2 in 


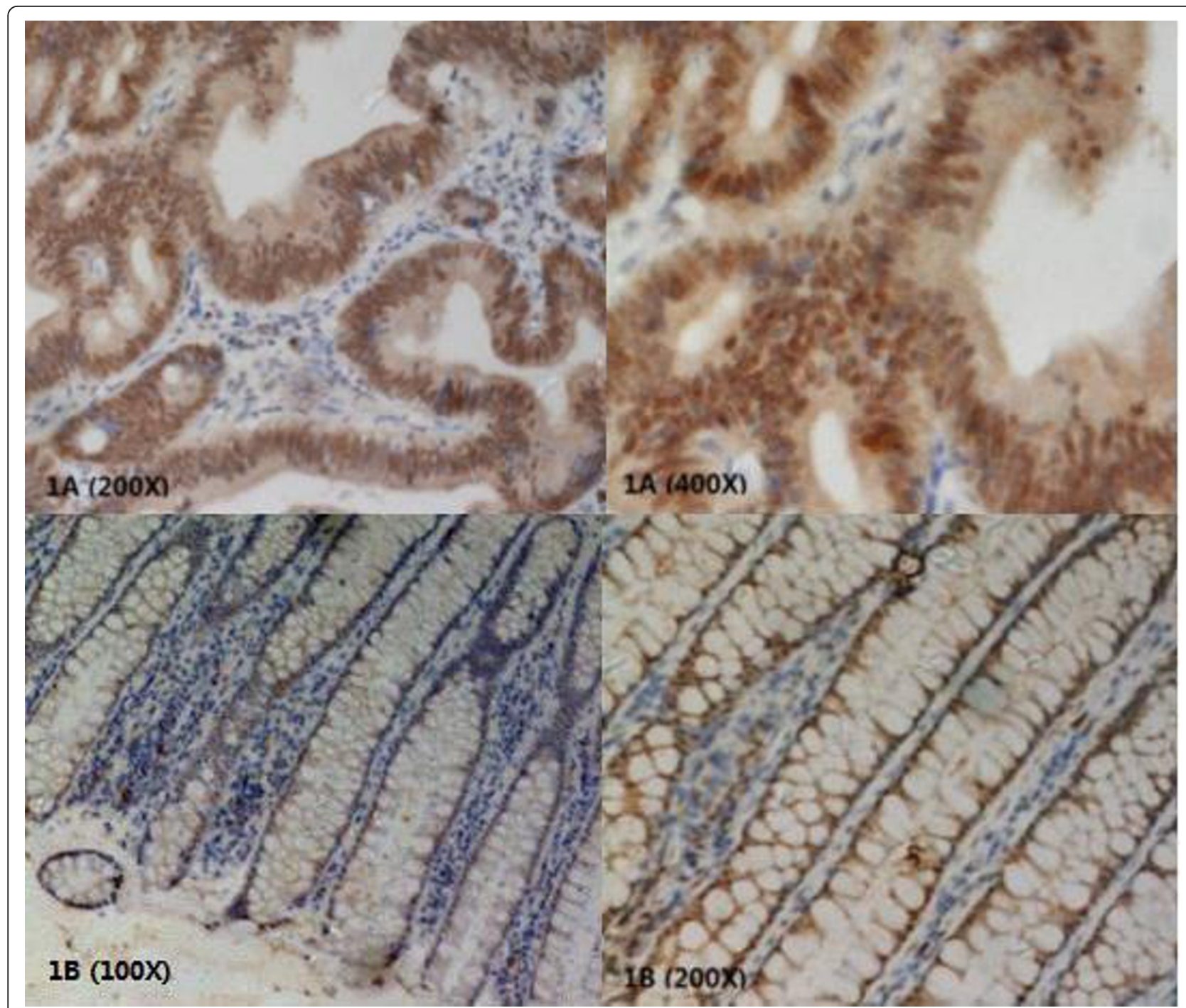

Figure 1 1A Immunohistochemical analyses of hPer2 protein positively expression in the colorectal cancerous tissues $(200 \times / 400 \times)$. $1 B$ Immunohistochemical analyses of hPer2 protein positively expression in the paired non-cancerous colorectal tissues(100x/200x).

colorectal cancer compared with non-cancerous components were 1: 1.219 .

\section{Discussion}

Studies in breast cancer and hepatic carcinoma have suggested that disturbed hPer2 gene expression is associated with human tumor progression [26,27]. Genetic studies then have provided direct evidence to show that mPer2 is a tumor suppressor in mice $[10,28]$. Whether this clock gene Per2 serves a similar role in human CRC is unclear. Aiming to investigate this question directly, in this study we first examined the protein expression of hPer2 in colorectal cancer patients. In order to make the cancerous and non-cancerous tissues be synchronized to the same circadian clock and be comparable, we analyzed and compared the expression status of the
hPer2 proteins between cancerous and non-cancerous cells of the same patient sample. The results revealed that hPer2 protein expressed in both colorectal carcinoma tissues (31 cases of the total 38 cases) and surrounding non-cancerous tissues (37 cases of the total 38 cases). By further comparisons of the average level of hPer2 protein expression in the paired tissues, significantly decreased hPer2 expression in these cancerous tissues were found (24 cases of the total 38 cases). In mammals, the rhythmic expression of Period genes is essential for creating a beating clock [2,29]. Homologues of most of the genes involved in the fly circadian clock have been cloned in mammals, and the general core clock mechanism of interacting transcriptional feedback loops is similar between flies and mice [30]. Abundant evidences generated from mammalian circadian rhythms 


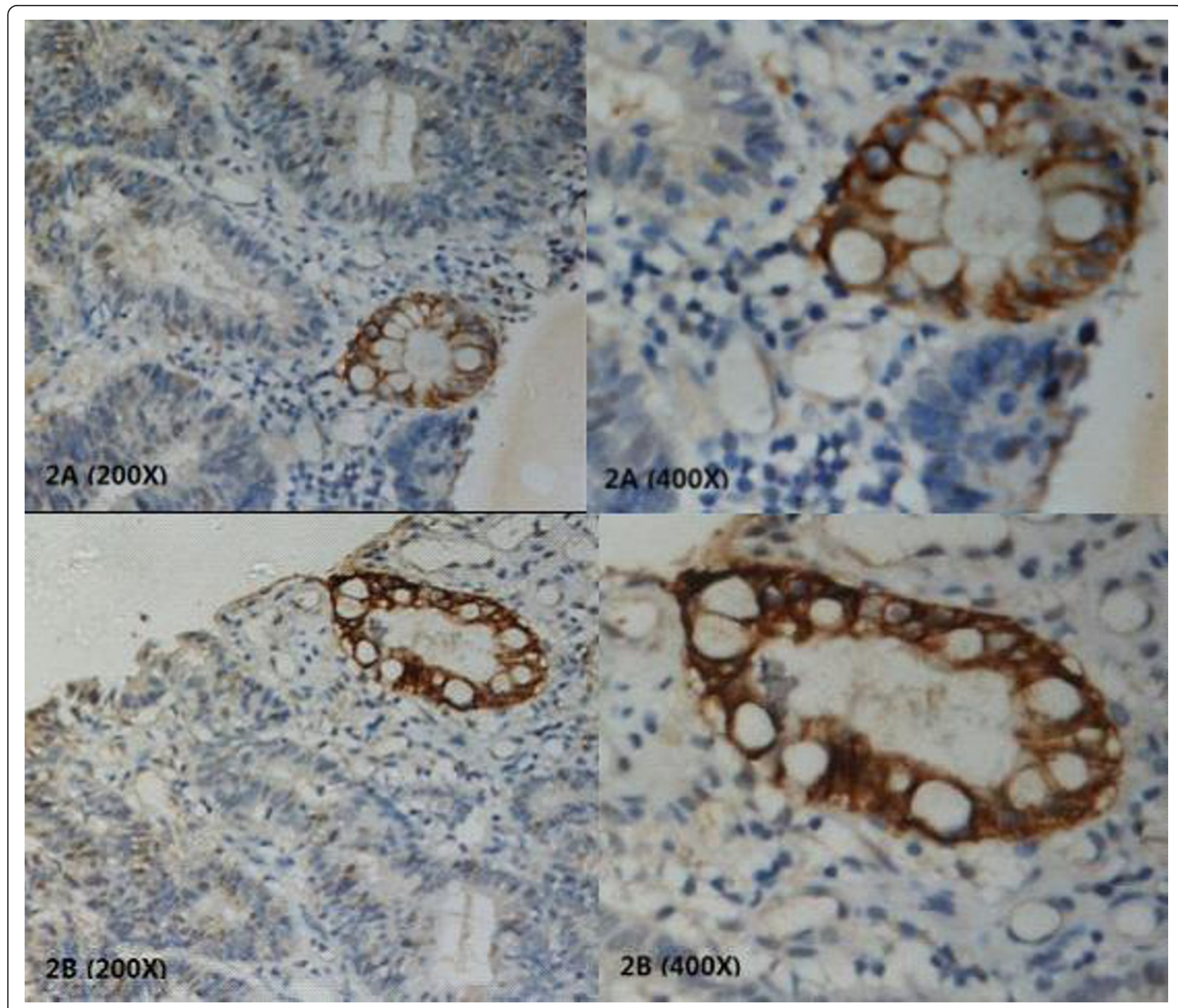

Figure 2 Immunohistochemical analyses of hPer2 protein heterogeneous expression in the colorectal cancerous tissues, positively stained in well-differentiated cells. $2 \mathrm{~A}$ and $2 \mathrm{~B}$ are two different individuals in which this interesting phenomenon can be found(200x/400x).

have indicated that disruption of mPer2 genes causes immediate behavioral arrhythmicity of mPer2 knock-out mouse [31-33]. Since the Per2 gene expression level decreased in the CRC tissues, our results may suggest that the circadian clock in most human CRC cases behaves arrhythmic, and differently from that in noncancerous cells.

Immunohistochemical analyses also showed differential expression patterns of hPer2 protein in our samples. Most colorectal cells in non-cancerous tissues were

Table 2 Relationship between expression levels of hPer2 protein in colorectal carcinoma and clinical features

\begin{tabular}{|c|c|c|c|}
\hline clinical-pathological features & $\begin{array}{l}\text { Total cases } \\
\mathrm{n}\end{array}$ & $\begin{array}{l}\text { Decreased hPer2 expression in tumor } \\
\mathrm{n}(\%)\end{array}$ & $P$ \\
\hline Sex & & & 0.357 \\
\hline $\begin{array}{l}\text { male } \\
\text { female }\end{array}$ & $\begin{array}{l}18 \\
20\end{array}$ & $\begin{array}{l}10(55.6) \\
14(70.0)\end{array}$ & \\
\hline Age & & & 0.017 \\
\hline $\begin{array}{l}\leq 50 \\
>50\end{array}$ & $\begin{array}{l}8 \\
30\end{array}$ & $\begin{array}{l}8(100.0) \\
16(53.3)\end{array}$ & \\
\hline Tumor site & & & 0.393 \\
\hline colon & 21 & $12(57.1)$ & \\
\hline rectum & 17 & 12(70.6) & \\
\hline
\end{tabular}


Table 3 Relationship between expression levels of hPer2 protein in colorectal carcinoma and pathological features

\begin{tabular}{|c|c|c|c|}
\hline clinical-pathological features & $\begin{array}{l}\text { Decreased hPer2 expression in tumor } \\
\mathrm{n}\end{array}$ & $\begin{array}{l}\text { Non-Decreased hPer2 expression in tumor } \\
\mathrm{n}\end{array}$ & $P$ \\
\hline Pathology Type & & & 0.235 \\
\hline $\begin{array}{l}\text { protrude } \\
\text { infiltrating } \\
\text { ulcer }\end{array}$ & $\begin{array}{l}7 \\
3 \\
14\end{array}$ & $\begin{array}{l}8 \\
1 \\
5\end{array}$ & \\
\hline Histological Grade & & & 0.017 \\
\hline $\begin{array}{l}\text { I, I } \\
\text { III }\end{array}$ & $\begin{array}{l}16 \\
8\end{array}$ & $\begin{array}{l}14 \\
0\end{array}$ & \\
\hline Depth of Tumor Invasion & & & 0.044 \\
\hline $\begin{array}{l}\mathrm{T}_{\mathrm{is}} \sim \mathrm{T}_{2} \\
\mathrm{~T}_{3} \sim \mathrm{T}_{4}\end{array}$ & $\begin{array}{l}3 \\
21\end{array}$ & $\begin{array}{l}6 \\
8\end{array}$ & \\
\hline Lymph Nodes Spread & & & 0.043 \\
\hline $\begin{array}{l}\text { negative } \\
\text { positive }\end{array}$ & $\begin{array}{l}10 \\
14\end{array}$ & $\begin{array}{l}11 \\
3\end{array}$ & \\
\hline TNM Stage & & & 0.021 \\
\hline $\begin{array}{l}\text { I } \\
\text { III+IV }\end{array}$ & $\begin{array}{l}2 \\
8 \\
14\end{array}$ & $\begin{array}{l}6 \\
5 \\
3\end{array}$ & \\
\hline p53 & & & 0.167 \\
\hline $\begin{array}{l}(-) \\
(+)\end{array}$ & $\begin{array}{l}2 \\
22\end{array}$ & $\begin{array}{l}4 \\
10\end{array}$ & \\
\hline C-erB-2 & & & 0.80 \\
\hline $\begin{array}{l}(-) \\
(+)\end{array}$ & $\begin{array}{l}13 \\
11\end{array}$ & $\begin{array}{l}7 \\
7\end{array}$ & \\
\hline
\end{tabular}

homogeneously stained. In contrast, in the paired cancerous tissues, heterogeneous staining manifested commonly. The cancerous cells were positively or strongly stained in some areas while negatively or weakly stained in other areas of the same tissue. It suggests that several asynchronized circadian clocks may operate in different sub-populations within the same tumor simultaneously. Furthermore, in cancerous tissues, well-differentiated cells seem to have higher level of hPer2 compared to that in the poorly-differentiated cells. This phenomenon may suggest that inactivation of hPer2 not only correlates with colorectal tumor initiation but also plays a role in tumor progression.

We further analyzed hPer2 expression patterns with clinical-pathological features of these colorectal tumor tissues. We found that cancerous tissues with high grades of histopathological changes and advanced stages of TNM classification showed statistically weaker hPer2 protein expression, especially in those patients under 50 . Since these clinical-pathological features correlate with

Table 4 Relationship between the reduced expression of hPer2 protein and Ki67 in colorectal cancer patients

\begin{tabular}{llll}
\hline low hPer2 expression in tumor & \multicolumn{2}{l}{ Ki67 } & \\
\cline { 2 - 4 } & $\mathbf{n}$ & $\bar{x} \pm \mathbf{s}$ & $\mathbf{P}$ \\
\hline Negative & 14 & $0.476 \pm 0.262$ & 0.046 \\
Positive & 24 & $0.638 \pm 0.214$ & \\
\hline
\end{tabular}

relatively poor prognosis of colorectal cancer patients, low hPer2 expression may be utilized as one of the prognostic biomarkers for colorectal cancer and worth further investigation in a larger sample set. In our study, a relation of low expression of hPer2 in tumor tissues with strong Ki67 was also found. It suggests that deregulated expression of hPer2 may contribute to the highly proliferative property of colorectal cancer cells. Previous studies have shown that aberrant expression of circadian clock genes could have important consequences on the transactivation of downstream targets that control the cell cycle and on the ability of cells to undergo apoptosis, potentially promoting carcinogenesis $[1,2]$. C-erB-2 and p53 were shown to be partly controlled by hPer 2 in the course of tumor progression $[6,10]$. However, in this study, we observed no statistically significant association between low levels of hPer2 expression and positive p53 or C-erB-2, which need to be further investigated in a larger sample set.

Recently, more direct evidences demonstrate the link between the loss of circadian genes function and cancer progression, but the underlying mechanisms were poorly understood. Chen ST. et al. reported that $95 \%$ of breast tumors (56 out of 59 specimens) displays no or deregulated level of Per1, Per2 or Per3 proteins in the breast tumor cells when compared the adjacent normal tissues [6]. Yeh et al. found that the expression level of Per1 was significantly decreased in endometrial carcinoma 


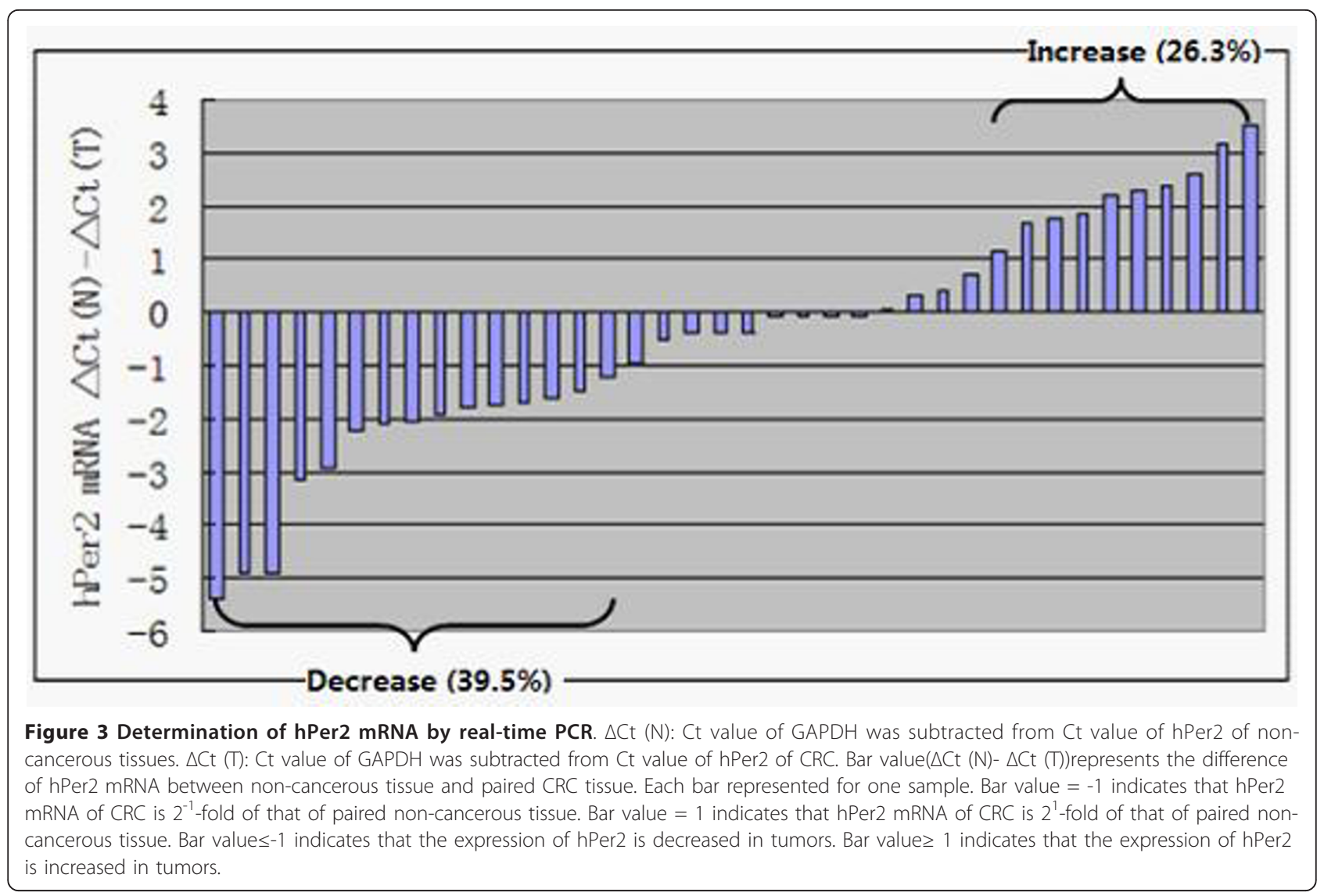

[34]. In these studies, the loss of clock gene expression was due to DNA methylation of the promoters rather than gene mutations of the clock genes. Later, Remco et al. identified the miR-192/194 cluster as a potent inhibitor of the entire Period gene family using a forward genetic screen, unveiling a new mechanism for the downregulation of the circadian clock genes at the posttranscriptional level [35]. To elucidate a possible mechanism to explain the hPer2 expression patterns in colorectal cancer, we further analyzed hPer2 mRNA levels in these 24 paired tissues which showed low expression of Per2 protein in tumor. Our results showed that the mRNA levels of Per2 were also decreased in cancerous tissues. It suggests that other factors rather than miR-192/194 cluster may be responsible for the hPer2 gene deregulation in CRC progression. Since it has been shown that $\mathrm{CpG}$ methylation can inactivate promoter function, leading to inhibition of hPer gene promoter function in breast and endometrial carcinoma, whether CpG methylation on the PER2 promoter contributes to human colorectal cancer development needs further investigation.

Both genetic and molecular studies have shown that $\mathrm{hPer} 2$ is a tumor suppressor that controls cell proliferation and promotes apoptosis. Our data suggest that aberrant expression of the hPer2 gene may be associated with the development of carcinomas in the colorectal tissues and may provide a molecular basis for the clinical application of chronotherapy in CRC treatment. However, the mechanisms leading to the reduced expression of hPer2 and the manner in which hPer2 suppresses tumorigenesis remains unclear. Further studies are still necessary to elucidate the role of hPer2 in CRC.

\section{Conclusions}

Our study showed hPer2 expression decreased in human CRC tissues, and well-differentiated cancer cells are more likely to maintain hPer2 expression than poorlydifferentiated ones. Furthermore, associations of decreased hPer2 levels with patients' age, histological grade, TNM stage and expression of nucleus proliferation related antigen: Ki67 were also detected. These results suggest a role for hPer2 in normal colorectal cell function and the potential deregulation of hPer2 expression in the development, invasion, and metastasis of CRC.

\section{Acknowledgements}

This work was supported by grants from the National Natural Science Foundation of China (81070234 and 81000355). 


\section{Author details}

'Department of Surgery, Huashan Hospital, Fudan University, Shanghai, China. ${ }^{2}$ Department of Physiology and Pathophysiology, Shanghai Medical College, Fudan University, Shanghai, China.

\section{Authors' contributions}

WYP collected the cases and clinical information, assisted in performing the study experiments, performed the statistical analysis and drafted the manuscript. LC carried out the immunoassays, analyzed pathological slides, and performed quantitative RT-PCR studies. CZY participated in the study's design and coordination. HLC conceived the study, pooled resources to perform the study experiments, performed study experiments, pathological slides analysis, preparation of manuscript, and editorial review, final editing and proofing prior to submission as corresponding author. All authors read and approved the final manuscript.

\section{Competing interests}

The authors declare that they have no competing interests.

Received: 8 September 2011 Accepted: 13 December 2011 Published: 13 December 2011

\section{References}

1. Gery S, Koeffler HP: The Role of Circadian Regulation in Cancer. [J] Cold Spring Harb Symp Quant Biol 2007, 72:459-464.

2. Misty CG, Cheng CL, Lee CC: Tumor Suppression and Circadian Function. [J] Journal of Biological Rhythms 2007, 22(4):291-298.

3. Ko CH, Takahashi JS: Molecular components of the mammalian circadian clock. []] Hum Mol Genet 2006, 15(2):R271-277.

4. Koyomi M, Miyuki W, Yasuhiro H, Ishida N: Tumor growth suppression in vivo by overexpression of the circadian component, PER2. [J] Genes to Cells 2010, 15(4):351-358.

5. Yang XM, Wood PA, Ansell C, Hrushesky WJM: Circadian time-dependent tumor suppressor function of Period genes. [J] Integrative Cancer Therapies 2009, 8(4):309-316.

6. Chen ST, Choo KB, Hou MF, Yeh KT, Kuo SJ, Chang JG: Deregulated expression of the PER1, PER2 and PER3 gene in breast cancer. [J] Oxford University Press 2005, 26(7):1241-1246.

7. Gery S, Gombart AF, Yi WS, Koeffler C, Hofmann WK, Koeffler HP: Transcription profiling of C/EBP targets identifies Per2 as a gene implicated in myeloid leukemia. [J] Blood 2005, 106(8):2827-2836.

8. Laurence C, Tomoko K, Vincent L: The days and Nights of cancer cells. [J] Cancer Research 2003, 63(22):7545-7552.

9. Filipski E: Host circadian clock as a control point in tumour progression. [J] Natl Cancer Inst 2002, 94(9):690-697.

10. Fu L, Pelicano H, Liu JS, Huang P, Lee CC: The circadian gene period2 plays an important role in tumor suppression and DNA damage response in vivo. [J] Cell 2002, 111(1):41-50.

11. Gery S, Virk RK, Chumakov K, Yu A, Koeffler HP: The clock gene Per2 links the circadian system to the estrogen receptor. [J] Oncogene 2007, 26(57):7916-7920.

12. Hua H, Wang Y, Wan C, Liu Y, Zhu B, Wang Z, Ding JM: Inhibition of tumorigenesis by intratumoral delivery of the circadian gene mPer2 in C57BL/6 mice. [J] Cancer Gene Ther 2007, 14(9):815-818.

13. Hua H, Wang Y, Wan C, Liu Y, Zhu B, Yang C, Wang X, Wang Z, CornelissenGuillaume G, Halberg F: Circadian gene mPer2 overexpression induces cancer cell apoptosis. [J] Cancer Sci 2006, 97(7):589-596.

14. Bjarnason GA, Jordan RC, Wood PA, Li Q, Lincoln DW, Sothern RB, Hrushesky WJ, Ben-David Y: Circadian expression of clock genes in human oral mucosa and skin: association with specific cell-cycle phases. [J] Am J Pathol 2001, 158(5):1793-1801.

15. Orr MS, O'Connor PM, Kohn KW: Effects of c-erbB2 overexpression on the drug sensitivities of normal human mammary epithelial cells. [J] Natl Cancer Inst 2000, 92(12):987-994.

16. Karnes WJ, Weller SG, Adjei PN, Kottke TJ, Glenn KS, Gores GJ, Kaufmann SH: Inhibition of epidermal growth factor receptor kinase induces proteasedependent apoptosis in human colon cancer cells. [J] Gastroenterology 1998, 114(5):930-939.

17. Vogelstein B, Lane D, Levine AJ: Surfing the $p 53$ network. [J] Nature 2000 408(6810):307-310
18. Rebecca S, Ahmedin J: Colorectal Cancer Facts and Figures. American Cancer Society (ACS), Atlanta, Georgia; 2011 [http://www.cancer.org/ Research/CancerFactsFigures/ColorectalCancerFactsFigures].

19. Zheng S, Cai SR: Colorectal cancer epidemiology and prevention study in China. [J] The Chinese-German journal of clinical oncology 2003, 2(2):72-75.

20. Zhang EE, Liu AC, Hirota T, Miraglia LJ, Welch G, Pongsawakul PY, Liu X, Atwood A, Huss JW, Janes J, Su A, Hogenesch JB, Kay SA: A Genome-wide RNAi screen for modifiers of the circadian clock in human cells. [J] Cell 2009, 139(1):199-210.

21. Scheving LA: Biological clocks and the digestive system. [J] Gastroenterology 2000, 119(2):536-549.

22. Innominato PF, Focan C, Gorlia T, Moreau T, Garufi C, Waterhouse J, Giacchetti S, Coudert B, Lacobelli S, Genet D, Tampellini M, Chollet P, Lentz MA, Mormont MC, Levi F, Bjarnason GA: Circadian rhythm in rest and activity: a biological correlate of quality of life and a predictor of survival in patients with metastatic colorectal cancer. []] Cancer Res 2009, 69(11):4700-4707.

23. Keith I, Penny B, Susan R, Jamie S, April Y, Michael D, Deva N, Peter T, Amanda K, Charlotte G: Making circadian cancer therapy Practical. [J] Integr Cancer Ther 2009, 8(4):371-386.

24. Giachetti S, Perpoint B, Zidani R, Bail L, Faggiuolo R, Focan C, Chollet P, Llory JF, Letourneau Y, Coudert B, Bertheaut-Cvitkovic F, LarregainFournier D, Rol AL, Walter S, Adam R, Misset JL, Levi F: Phase III multicenter randomized trail of oxaliplatin added to chronomodulated fluorouracil-leucovorin as first-line treatment of metastatic colorectal cancer. [J] J Clin Oncol 2002, 18(1):136-147.

25. Sylvie G: Chronotherapy of colorectal cancer. [J] Chronobiology International 2002, 19(1):207-219.

26. Yang XM, Wood PA, Oh EY, Du-Qution J, Ansell CM, Hrushesky WJM: Down regulation of circadian clock gene Period 2 accelerates breast cancer growth by altering its daily growth rhythm. [J] Breast Cancer Res Treat 2009, 117(2):423-431.

27. Lin YM, Chang JH, Yeh KT, Yang MY, Liu TC, Lin SF, Su WW, Chang JG: Disturbance of circadian gene expression in hepatocellular carcinoma. [J] Molecular Carcinogenesis 2008, 47(12):925-933.

28. Lee CC: Tumor suppression by the mammalian Period genes. [J] Cancer Causes Control 2006, 17(4):525-530.

29. Toh KL, Jones CR, He Y, Eide EJ, Hinz WA, Virshup DM, Ptacek LJ, Fu YH: An hPer2 phosphorylation site mutation in familial advanced sleep phase syndrome. [J] Science 2001, 291(5506):1040-1043.

30. Reppert SM, Weaver DR: Coordination of circadian timing in mammals. [J] Nature 2002, 418(6901):935-941.

31. Bae K, Jin X, Maywood ES, Hastings MH, Reppert SM, Weaver DR: Differential functions of mPer1, mPer2, and mPer3 in the SCN circadian clock. [J] Neuron 2001, 3(2):525-536.

32. Zheng B, Albrecht U, Kaasik K, Sage M, Lu W, Vaishnav S, Li Q, Sun ZS, Eichele G, Bradley A, Lee CC: Nonredundant roles of the mPer1 and mPer2 genes in the mammalian circadian clock. [J] Cell 2001, 105(5):683-694.

33. Zheng Binhai Larkin, David W, Albrecht Urs, Sun Zhong Sheng, Sage Marijke, Eichele Gregor, Lee Cheng Chi, Bradley Allan: The mPer2 gene encodes a functional component of the mammalian circadian clock. [J] Nature 1999, 400(6740):169-173.

34. Yeh KT, Yang MY, Liu TC, Chen JC, Chan WL, Lin SF, Chang JG: Abnormal expression of period 1 (PER1) in endometrial carcinoma. [J] J Pathol 2005, 206(1):111-120.

35. Remco N, Linda C, Reuven A: The miRNA-192/194 cluster regulates the Period gene family and the circadian clock. [J] FEBS Journal 2009, 276(19):5447-5455.

\section{doi:10.1186/1477-7819-9-166}

Cite this article as: Wang et al.: Expression of circadian clock gene human Period2 (hPer2) in human colorectal carcinoma. World Journal of Surgical Oncology 2011 9:166. 